\title{
Consumer Behavior towards Online Shopping: An Empirical Study from Delhi
}

\author{
${ }^{1}$ Ms. Dipti Jain, ${ }^{2}$ Ms. Sonia Goswami, ${ }^{3}$ Ms. Shipra Bhutani \\ ${ }^{1,2,3}$ Assistant Professor, Chanderprabhu Jain College of Higher Studies \& School of Law
}

\begin{abstract}
In today's era of internet proliferation, the prevalence of online shopping has increased. Internet has made the transactions smoother, quicker, faster and easier and both the buyers and sellers get benefited by his technology. The growing use of internet in India has created a basis for tremendous prospects for online retailers; knowledge of factors affecting consumer buying behavior can help retailers develop their marketing strategies to convert their potential consumers into active one. In this study four dimensions of online shopping as perceived by consumers in India are identified and the different demographic factors are also studied which are the primary basis of market segmentation for retailers. The main objective of this research is to study the impact of Perceived Risk, Perceived enjoyment, Perceived usefulness and Perceived ease of use factors on online shopping behavior of consumers in Delhi. The population of this research consisted of online shoppers from Delhi. The sample of the study comprised of 160 online shoppers. Respondents belonged to different age groups, income groups and occupations and have a prior experience in online shopping. A pre - structured questionnaire was used with a 5 point Likert rating scale to measure the factors influencing the respondent's behavior to shop online. The empirical results revealed that only one factor, namely Perceived Risk significantly affected online shopping behavior of consumers in Delhi while Perceived enjoyment, Perceived ease of use and Perceived enjoyment hinders the consumers to shop online so the researchers suggests that the companies must focus on Perceived risks to develop consumers trust towards online shopping. The recommendations presented in this research may help foster growth of Indian online retailing in future. The research findings revealed that perceived risk negatively impact consumers attitude towards online shopping while perceived usefulness, perceived ease of use and perceived enjoyment has no impact on consumers' attitude towards online shopping.
\end{abstract}

Keywords: Online shopping, Consumer behavior, Perceived risk, Perceived ease of use, Perceived usefulness, Perceived enjoyment.

\section{Introduction}

E-commerce is selling of goods and services via electronic media to facilitate exchange of detailed information between buyers and sellers. Online shopping has become an integral part of business. Online shopping refers to the shopping behavior of consumer in an online store or a website used for online purchasing purpose ( Monsuwe et al. 2004).

The Indian e- commerce market is estimated to be Rs. 50,000 crore, witnessing a rapid growth rate and has increased by $500 \%$ since 2007 . With the advent of $21^{\text {st }}$ century, the world has entered in an "e-generation" era. Internet technologies have revolutionized communication across the world and transformed the world into a global village. According to internet world stats India stood at the $3^{\text {rd }}$ rank with 137 million users till June 30 , 2012 (source: www.internet worldstats.com).

A large body of research is available on the online shopping in the world. However, there is still a need for closer examination on the online shopping as it is still at the early stage of development in India, little is known about consumers' attitude towards adopting this new shopping channel and factors that influence their attitude (Aque, Sadeghzadeh, \& Khatibi, 2006). The consumers' attitude towards online shopping is known as the main factors that affects e-shopping potential (Shwu-Ing, 2003). Therefore, understanding consumer attitudes towards e-shopping helps marketing managers to foresee the e-shopping rate and assess the future expansion of online commerce.

In this paper extended technology acceptance model (TAM Davis, 1989) is used to understand the variables that affect online shopping. Technology acceptance model is a foundation for examination of customers approval of online shopping (Stoel and Ha, 2009). Perceived ease of use (PEOU) and perceived usefulness (PU) are the two external variables of TAM (Davis , 1989).In this paper technology acceptance model is extended by accumulating perceived enjoyment (PE) and Perceived risk(PR) as a $3^{\text {rd }}$ and $4^{\text {th }}$ external variables that affects online shopping intention.

Perceived usefulness is the perception of an individual that usage of new system will help her /him to achieve gains in their work performance. Perceived ease of use is the perception of an individual that it requires no cost or effort in the adoption of new system or technology. Perceived enjoyment is the individual perception that by adopting new system or technology he/she will have pleasure. Perceived risk is that level of risk a 
consumer believes exists regarding the purchase of a specific product from a specific retailer, whether or not that belief is actually correct. This paper reveals that PE, PU, PEOU and PR significantly affect online shopping behavior of consumers.

\section{Literature Review}

A review of the related research work shows that the theory of Technology Acceptance Model (TAM) (Davis, 1989) is among the most popular theory used to explain online shopping behavior. Therefore, the theoretical framework of this study is based on this theory. The classic Theory of Technology Acceptance Model (TAM) has been extensively adopted for explaining and predicting user behavior in an online shopping environment. The TAM posits that actual system use is determined by users' behavioral intention to use, which is, in turn, influenced by their attitude toward usage. Attitude is directly affected by users' belief about a system, which consists of perceived usefulness and ease of use (Davis 1986).In construction/development of the TAM, perceived usefulness and perceived ease of use reflect the utilitarian aspects of online shopping, while perceived enjoyment reflects the hedonic aspects of online shopping. Past research shows that perceived usefulness and perceived ease of use reflect utilitarian aspects of online shopping, whereas perceived enjoyment reflects hedonic aspects of online shopping (Monsuwe et al., 2004).Based on technology acceptance model, (An and Wang, 2007) built a comprehensive conceptual model of online shopping intention, which comprised external variable and intervene variable. The former includes consumer personality, perception of website characteristics and perception of online retailer feature, while the latter includes perceived usefulness, perceived ease and credibility. Both external variable and intervene variable have significant effect on consumer intention of online shopping. These studies are mainly about consumer behavior on online shopping( Menon and Kahn, (2002); Childers et al., (2001); Mathwick et al., (2001) concluded that Online shopping features can be either consumers' perceptions of functional and utilitarian dimensions, like "ease of use" and "usefulness", or their perceptions of emotional and hedonic dimensions like "enjoyment by including both utilitarian and hedonic dimensions, aspects from the information systems or technology literature, as well as the consumer behavior literature are integrated in our framework. (Burke et al., (2002) In addition to these relevant online shopping features, also exogenous factors are considered that moderate the relationships between the core constructs of the framework.

Online Shopping Online shopping is the consumers shopping behavior to shop online. The people who find it easy to use, useful and enjoyable can accept online shopping. Technology acceptance model is used to understand the variables that affect online shopping. These variables are perceived risk, perceived usefulness, perceived ease of use and perceived enjoyment. These variables and their effects on online shopping are explained as follows:

\section{Perceived risk}

Perceived risk can be defined as the subjective belief of consumer suffering a loss in search of a desired outcome. It has stronger correlation with willingness to shop online than convenience (Zhou et al., 2007: Van Noort et al. 2007). According to Kim et. al. (2007), perceived risk is a consumer's belief about possible uncertain negative results from any electronic operation. Wang et al. (2006) mentioned in their study that safety, personal privacy and service or product quality are the mandatory concern areas of the consumer who like to do on-line transaction. According to Liao and Shi (2009), perceived risk has a negative and significant influence on consumer buying attitude towards online shopping, for instance e-retailing. Li \& Zhang (2002) mentioned perceived risk is an important element of consumer attitude towards online shopping behavior. There are generally two elements of perceived risk which are associated with the process of online shopping: risk related to the context of online transaction and risk related to the product or service. Liebermann \& Stashevsky (2002) stated that there are two elements of perceived risk related to the process of online shopping. These are: Internet credit card stealing and confidentiality of consumer's personal information. One can't eliminate perceived risk because there is no physical interaction but it can be changed by the association with transaction processes (Pavlou, 2003; Koufaris and Hampton-Sosa, 2004) or consumer trust on online transactions (Culnan and Armstrong, 1999; Warrington, et al., 2000; Park and Jun, 2003; Koufaris and Hampton-Sosa, 2004; Gefen and Pavlou, 2006).Privacy and security of online shopping and perceived risks are important barriers in front of internet shopping and retailers should develop some precautions while handle these drawbacks(Miyazaki \& Fernandez, 2001). Security and privacy of online shopping attracts researcher attentions (Järveläinen, 2007).

Web sites most important role is to ensure customers concerning their financial data and private data. Most of the sites try different ways to protect customer data. They try to improve their security precautions and payment methods. If consumers trust the internet shopping web sites their intention to purchase would increase. The issue of payment security affects not only new internet shoppers but also existing internet shoppers (Kwon \& Lee, 2003). Some existing internet shoppers avoid to shop online because of payment security issue. And they can 
influence the people around them. While end users use internet on regular basis, because of security and privacy issues they abstain from internet shopping (Lian \& Lin, 2008).

\section{Perceived enjoyment}

Consumers who are hedonist have experiential shopping behavior. Hedonists not only gather information to shop online but also seek fun, excitement, arousal, joy, festive, escapism, fantasy, adventure, etc. (Monsuwe et al., 2004). These experiential shoppers want to be immersed in the experience rather than to achieve their goals by shopping online (Wolfinbarger and Gilly, 2001) and their perceived experiences also depend on the medium characteristics that induce enjoyable experiences (Sorce etal., 2005). The degree of interactivity that a Web site offers is a strong factor in support of establishing this relationship, because experiential shoppers usually find more enjoyment in interactive environments than in pure text environments (Childers et al., 2001).

Enjoyment in shopping can be two-fold: enjoyment from the product purchased as well as the process of shopping itself. Online shopping like in-store shopping, provided both types of enjoyment and such enjoyment can positively or negatively influence online shopping (Eastlick \& Liu, 1997; Forsythe \& Bailey, 1996; Kunz, 1997; Taylor \& Cosenza, 1999).

Childers et al (2001) concluded that "enjoyment" results from the fun and playfulness of the online shopping experience, rather than from shopping task completion. The purchase of goods may be incidental to the experience of online shopping. Thus, "enjoyment" reflects consumers' perceptions regarding the potential entertainment of internet shopping found "enjoyment" to be a consistent and strong predictor of attitude toward online shopping ( Menon and Kahn, 2002; Mathwick et al., (2001) says that if consumers enjoy their online shopping experience, they have a more positive attitude toward online shopping, and are likely to adopt the Internet as a shopping medium. In our framework, we identify three latent dimensions of "enjoyment" construct, including "escapism", "pleasure", and "arousal". "Escapism" is reflected in the enjoyment that comes from engaging in activities that are absorbing, to the point of offering an escape from the demands of the day-to-day world. "Pleasure" is the extent to which a person feels good, joyful, happy, or satisfied in online shopping.

\section{Perceived ease of use:}

Davis (1989), defined Perceived Ease of Use (PEOU) as the degree to which a person believes that using a particular system would be free from effort. Ease of use can also be defined as a person's perception that using the new technology will be free from effort (Davis, 1989, 1993). Perceived Ease of Use (PEOU) has a significant and positive influence on consumers' attitude about e-shopping (Bisdee, 2007; Yulihasri \& Daud, 2011).The elements of Perceived Ease of Use (PEOU) are the easy system, process, elastic and effortless to become skillful. According to Selamat et al. (2009) easier technology is always easily accepted by the consumers rather than complex technology for online shopping. Usually consumers do not wish to use complex technology for buying any product or service online. Meanwhile website characteristics play a major role in determining perceived ease of use in online shopping (Zeithaml et al., 2002; Beldona et al.2005).

\section{Perceived usefulness}

In perspective of e-shopping, perceived usefulness is customers' perception that by shopping online his or her performance will be enhanced. Perceived usefulness (PUSF) is considered as the utilitarian factor that affects online shopping (Davis, 1989). According to TAM (Davis, 1989) customers tend to use that online website which significantly affects their performance. According to Zhou et al. (2007) it's the customer's probability that shopping online would increase his/her efficiency and this positively affect the entire purchase process. Bhattacherjee, (2001) says that customer prefer to acquire a product when such usage is perceived to be useful.

\section{Objective Of The Study}

1. To know the demographic profile of the customers and its impact if any on the online buying.

2. To determine the factors affecting the perception of Indian online buyers.

\section{Materials And Model}

In this study, the research model (Figure 1) that was adhered to examine the factors affecting online shopping contains constructs that have demonstrated literature support, and is based on a body of research done in this area in different countries, particularly online shopping on end-user perspective. 


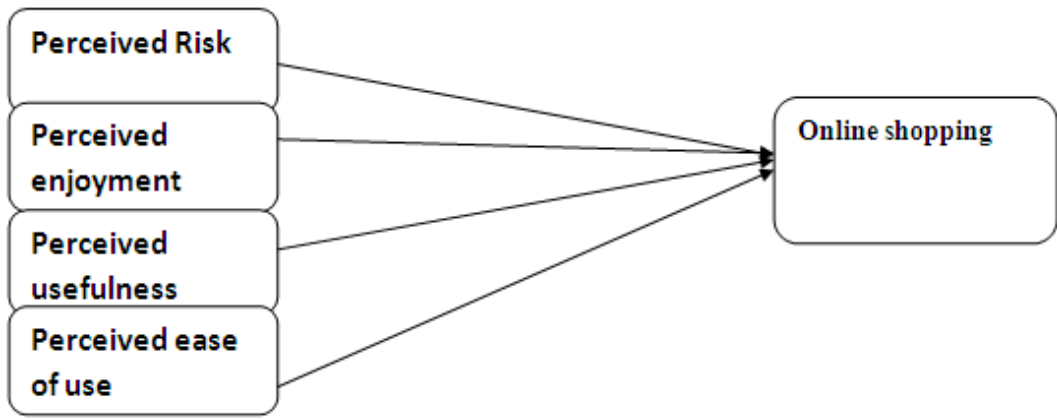

Figure-1. Proposed Research Model

\section{Research Model}

The schematic diagram of the research model above shows the relationship between the dependent and independent variables. Attitude toward online shopping is the dependent variable in this research. The dependent variable is analyzed in order to find out the answers or solution to the problem. Meanwhile, the independent variables in this research are perceived risk, perceived enjoyment, perceived usefulness and perceived ease of use. The independent variables are believed to be the variables that influence the dependent variable (attitude toward online shopping) in either a positive or a negative way.

\section{Hypothesis}

The following hypotheses were developed from the proposed research model:

H1: There is a significant relationship between perceived risk and attitude toward online shopping.

H1a: There is no significant relationship between perceived risk and attitude toward online shopping

H2: There is a significant relationship between perceived enjoyment and attitude toward online shopping

H2a: There is no significant relationship between perceived enjoyment and attitude toward online shopping

H3: There is a significant relationship between perceived ease of use and attitude toward online shopping

H3a: There is no significant relationship between perceived ease of use and attitude toward online shopping

H4: There is a significant relationship between perceived usefulness and attitude toward online shopping.

H4a: There is no significant relationship between perceived usefulness and attitude toward online shopping.

\section{Research Methodology}

POPULATION AND SAMPLE: Researchers like (Davis, Monsuwe, Dellaert, Ruyter, Stoel )explored that the youth are the main buyers who use the internet to buy the products online. So, as the universe of this study, the researchers considered higher education students in Delhi who used the internet for different purposes and who are above the age of 18 years. The current study utilizes a non-probability sampling techniques that is convenience sampling. In this study, the researchers collected the primary data through distribution of survey questionnaires. The researchers developed a self-structured questionnaire to collect the required primary data. The principal component analysis was conducted with 100 respondents. Apart from that demographic information, respondents were asked to rate their opinion according to five point Likert rating scale, with rating five being "Strongly Agree" and one being "Strongly Disagree". The collected data was analyzed with the help of Statistical Package for Social Science (SPSS 17.0). Factor analysis is the basic tool that has been considered for data analysis.

\section{Development Of The Instrument}

The data for the study was gathered through a structured questionnaire. All variables were operationalized using the literature on online shopping (Babin, Darden, \& Griffin, 1994; Bruner \& Hensel, 1996; Forsythe et al., 2002; Huang \& Liaw, 2005; Hui, Tan, \& Goh, 2006; Kim \& Shim, 2002; Mathieson, 1991; Turban \& Gehrke, 2000; Vijayasarathy, 2002).

The first part of the questionnaire included questions concerning Demographic profile of the respondents. The second part consisted of questions measuring variables that may affect online shopping behavior of individuals.. All the questions/variables utilized a Likert scale ranging from 1 (strongly disagree) to 5 (strongly agree)

\section{Data Analysis}

\begin{tabular}{|l|c|c|}
\hline \multicolumn{2}{|c|}{ Table 1: Demographic Characteristics Of The Respondents } \\
\hline VARIABLES AND CATEGORIES & $\mathrm{F}(\mathrm{N}=160)$ & $\%$ \\
\hline
\end{tabular}


Consumer Behavior towards Online Shopping: An Empirical Study from Delhi

\begin{tabular}{|c|c|c|}
\hline \multicolumn{3}{|l|}{ GENDER } \\
\hline MALE & 84 & $52.5 \%$ \\
\hline FEMALE & 76 & $47.5 \%$ \\
\hline \multicolumn{3}{|l|}{ AGE } \\
\hline 18-29 YEARS & 134 & $84 \%$ \\
\hline 30-41 YEARS & 20 & $12 \%$ \\
\hline 41-50 YEARS & 6 & $4 \%$ \\
\hline \multicolumn{3}{|l|}{ MARITAL STATUS } \\
\hline MARRIED & 34 & $22 \%$ \\
\hline UNMARRIED & 126 & $78 \%$ \\
\hline \multicolumn{3}{|l|}{ INCOME } \\
\hline NO INCOME BUT POCKET MONEY & 110 & $69 \%$ \\
\hline LESS THAN 2 LAKHS & 10 & $6 \%$ \\
\hline 2 LACS-5 LACS & 26 & $16 \%$ \\
\hline 5 LACS AND ABOVE & 14 & $9 \%$ \\
\hline \multicolumn{3}{|l|}{ EDUCATIONAL QUALIFICATIONS } \\
\hline GRADUATION & 102 & $64 \%$ \\
\hline POST GRADUATION & 28 & $17.5 \%$ \\
\hline PROFESSIONAL & 18 & $11 \%$ \\
\hline OTHERS(SPECIFY) & 12 & $7.5 \%$ \\
\hline
\end{tabular}

\section{Data Analysis And Results}

\section{- Demographic characteristics}

The table 2 exhibits the demographic traits associated with the respondents considered for the purpose of this study. Frequency distribution profiles of respondents showed that $52.5 \%$.percent of the respondents were male while $47.5 \%$ of the remaining respondents were female. The majority of the respondents $(84 \%)$ fall in the age group between $18-29$ years. A majority of respondents (76\%) were single and $69 \%$ of the respondents had no income, but received pocket money. A maximum of $64 \%$ of the respondents were pursing their graduation degrees $17.5 \%$ post graduation degrees and only $11 \%$ were pursing professional degrees.

\section{- Results}

Consumer expectations and perception towards online shopping were examined in terms of perceived risk, perceived usefulness, perceived enjoyment and perceived ease of use. Factor analysis using SPSS for windows was conducted in order to identify the factors that affect the online shopping behavior of consumers. Factors were identified using the Eigen value criteria that suggests extracting factors with an Eigen value of greater than 1.0 Principal Component Analysis and Varimax
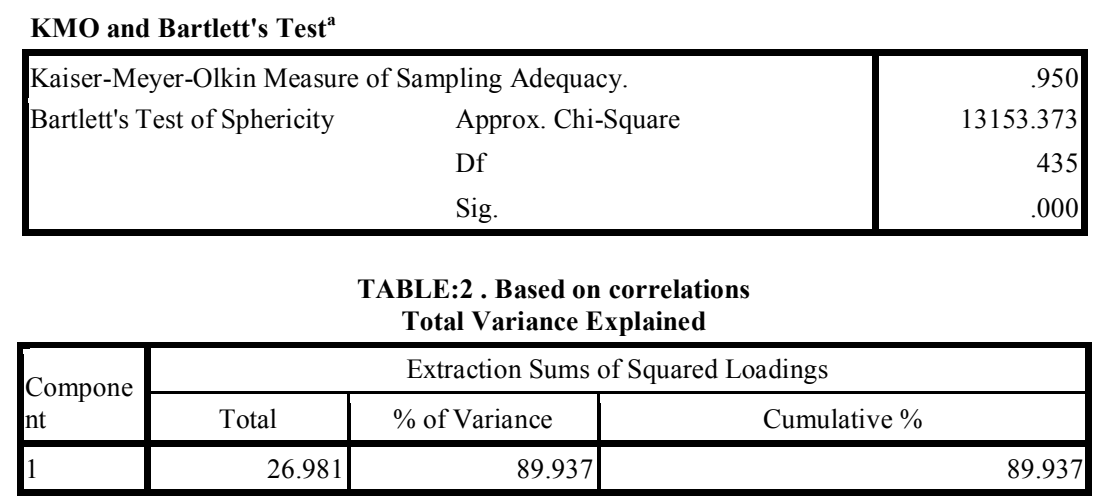

TABLE 3:Extraction Method: Principal Component Analysis

Rotation was considered for obtaining a component matrix. For confirming the adequacy and sphericity of the data set, Kaiser-Meyer-Olkin (KMO) and Bartlett's test values were also obtained. As seen from table, the KMO MEASURE of sampling adequacy score is .950, well above the recommended 0.5 level. Kaiser|(1974) recommended that to accept the KMO values of $>0.5$, a researcher should ensure the generation of reliable factors. Further, Bartlett's Test of sphericity exhibited significance value of less than 0.05(.000), thereby ensuring the appropriateness of factor analysis for this research work. The table 4 has exhibited the four factors extracted by factor analysis. Each factor has been defined by at least 5 variables, and all the extracted communalities after rotation are more than 0.5 , ensuring the appropriateness of factor analysis for this work. With regard to the result reported in table 3, factor 1 loaded with the 12 variables. As seen from the table 4, all these variables relate to risks associated with online shopping. 


\begin{tabular}{|c|c|c|c|c|c|c|}
\hline \multicolumn{7}{|c|}{ TABLE:4 EXPLORATORY FACTOR ANALYSIS } \\
\hline & \multicolumn{2}{|c|}{ DESCRIPTIVE } & \multicolumn{4}{|c|}{ FACTORS } \\
\hline & MEAN & SD & 1 & 2 & 3 & 4 \\
\hline $\begin{array}{l}\text { THE QUALITY OF THE PRODUCT PURCHASED } \\
\text { MAY NOT BE GOOD/GUARANTEED OR AS } \\
\text { ORDERED }\end{array}$ & 3.25 & .971 & .926 & & & \\
\hline THERE ARE CHANCES OF BEING CHEATED & 3.26 & .987 & .924 & & & \\
\hline $\begin{array}{l}\text { THERE IS A RISK OF RECEIVING PRODUCTS } \\
\text { LATE }\end{array}$ & 3.31 & .985 & .939 & & & \\
\hline $\begin{array}{l}\text { I MIGHT NOT RECEIVE THE PRODUCT AT THE } \\
\text { APPRORIATE TIME }\end{array}$ & 3.28 & .868 & .892 & & & \\
\hline $\begin{array}{l}\text { I FEEL THAT MY CREDIT CARD DETAILS MAY } \\
\text { BE MISUSED IF I SHOP ONLINE }\end{array}$ & 2.80 & 1.202 & .889 & & & \\
\hline $\begin{array}{l}\text { I FEEL THAT MY CREDIT CARD INFORMATION } \\
\text { MAY BE COMPROMISED TO THIRD PARTY }\end{array}$ & 2.91 & 1.112 & .899 & & & \\
\hline $\begin{array}{l}\text { I MIGHT NOT GET WHAT I ORDER THROUGH } \\
\text { ONLINE SHOPPING }\end{array}$ & 3.08 & 1.085 & .920 & & & \\
\hline $\begin{array}{l}\text { I MIGHT RECEIVE MALFUNCTIONING } \\
\text { /EXPIRED/SECONDHAND PRODUCTS }\end{array}$ & 2.89 & 1.133 & .910 & & & \\
\hline $\begin{array}{l}\text { HOME DELIVERY`BY A STRANGER MAY NOT } \\
\text { BE SAFE }\end{array}$ & 3.00 & 1.176 & .869 & & & \\
\hline $\begin{array}{l}\text { CASH ON DELIVERY OPTION MAY NOT BE } \\
\text { AVAILABLE }\end{array}$ & 2.84 & 1.192 & .915 & & & \\
\hline $\begin{array}{l}\text { GOODS MAY BE DAMAGED IN } \\
\text { TRANSPORTATION }\end{array}$ & 3.30 & .983 & .928 & & & \\
\hline $\begin{array}{l}\text { THE PRODUCT IS NON-RETURNABLE EVEN IF I } \\
\text { AM NOT FULLY SATISFIED AND EVEN IF IT IS } \\
\text { AVAILABLE ITS NOT CONVENIENT }\end{array}$ & 3.46 & 1.238 & .913 & & & \\
\hline $\begin{array}{l}\text { ITS NOT EASY TO CANCEL THE ORDERS WHEN } \\
\text { I SHOP ONLINE }\end{array}$ & 3.46 & 1.087 & .893 & & & \\
\hline \multicolumn{7}{|l|}{ PERCEIVED ENJOYMENT } \\
\hline $\begin{array}{l}\text { I SHALL HAVE FUN WHILE PURCHASING } \\
\text { PRODUCTS OVER INTERNET. }\end{array}$ & 3.68 & .805 & & .868 & & \\
\hline $\begin{array}{l}\text { USING THE INTERNET TO PURCHASE A } \\
\text { PRODUCT WOULD PROVIDE ME A LOT OF } \\
\text { ENJOYMENT. }\end{array}$ & 3.33 & .865 & & .899 & & \\
\hline $\begin{array}{l}\text { I THINK THAT PURCHASING PRODUCTS FROM } \\
\text { INTERNET SHALL BE INTERESTING. }\end{array}$ & 3.59 & .864 & & .901 & & \\
\hline $\begin{array}{l}\text { USING THE INTERNET TO PURCHASE A } \\
\text { PRODUCT WOULD PROVIDE ME A LOT OF } \\
\text { EXCITEMENT }\end{array}$ & 3.35 & .856 & & .892 & & \\
\hline $\begin{array}{l}\text { I ENJOY SURFING THE NET FOR THE PUPOSE } \\
\text { OF PURCHASING PRODUCT AND RECEIVING } \\
\text { INFORMATION. }\end{array}$ & 3.86 & .805 & & .837 & & \\
\hline \multicolumn{7}{|l|}{ PERCEIVED EASE OF USE } \\
\hline $\begin{array}{l}\text { LEARNING TO OPERATE THE INTERNET TO } \\
\text { BUY A PRODUCT WOULD BE EASY FOR ME. }\end{array}$ & 3.56 & 1.032 & & & .896 & \\
\hline $\begin{array}{l}\text { USING THE INTERNET AS A MEDIUM TO BUY A } \\
\text { PRODUCT WOULD BE FLEXIBLE TO INTERACT } \\
\text { WITH. }\end{array}$ & 3.30 & .917 & & & .918 & \\
\hline $\begin{array}{l}\text { MY INTERACTION WITH INTERNET TO BUY A } \\
\text { PRODUCT WILL BE CLEAR AND } \\
\text { UNDERSTANDABLE. }\end{array}$ & 3.50 & .869 & & & .905 & \\
\hline $\begin{array}{l}\text { THE INTERNET WOULD BE EASY TO BE USE TO } \\
\text { DO MY SHOPPING. }\end{array}$ & 3.73 & .824 & & & .860 & \\
\hline $\begin{array}{l}\text { IT WOULD BE EASY FOR ME TO BECOME } \\
\text { SKILLFUL FOR USING THE INTERNET TO BUY A } \\
\text { PRODUCT }\end{array}$ & 3.46 & 1.002 & & & .936 & \\
\hline $\begin{array}{l}\text { ONLINE ORDERING LAYOUT IS EASY AND } \\
\text { CONVENIENT }\end{array}$ & 3.61 & .890 & & & .873 & \\
\hline $\begin{array}{l}\text { ONLINE PRODUCT INFORMATION IS } \\
\text { CLEAR,PRECISE AND EASY TO UNDERSTAND. }\end{array}$ & 3.35 & .979 & & & .932 & \\
\hline \multicolumn{7}{|l|}{ PERCEIVED USEFULNESS } \\
\hline THE INTERNET WOULD IMPROVE MY & 3.48 & .897 & & & & .91 \\
\hline
\end{tabular}




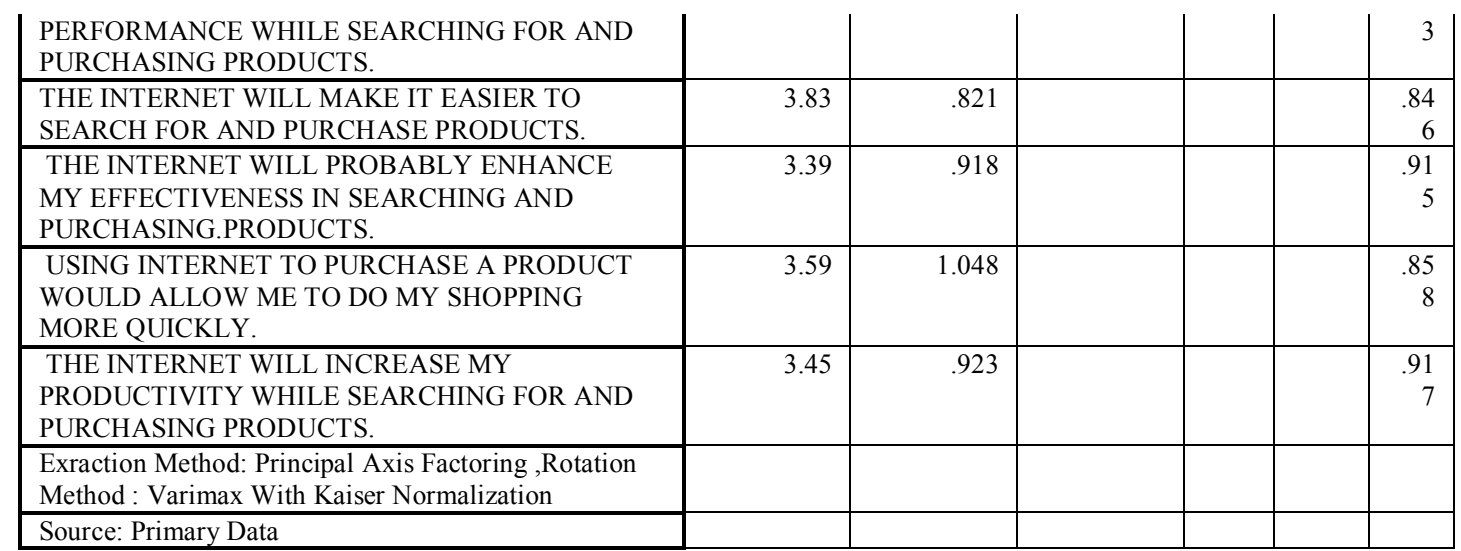

As shown in the above table, out of the four factors, the factor Perceived Risk got the highest overall mean score (40.84), the factor Perceived usefulness received the second highest overall mean score i.e. 24.51, the factor perceived enjoyment received a third highest overall mean score of 17.81 and the factor Perceived ease of use got the least overall mean score i.e. 17.74

\section{Conclusion}

The large numbers of studies have been conducted by various research scholars and academicians nationally and across the globe, exploring the factors that may affect online buying behavior of various consumers. This research work is an attempt to explore the factors that may affect the attitude of consumers in Delhi towards online shopping. The study was conducted by drawing a sample of 160 respondents pursuing higher education, professionals and employed through kwiksurvey.com and with various institutions among March 2014 to May 2014. Relying on existing literature; variables were considered and offered to respondents in form of a closed ended questionnaire to mark their responses on a five point Likert scale. The collected data was analyzed with the help of statistical package for social science (SPSS17). The results revealed four important factors viz. perceived risk, perceived enjoyment, perceived ease of use and perceived usefulness to be affecting the online shopping behavior of consumers in Delhi. As per the data collected and analyzed through SPSS17 it is clear that the hypothesis 1 has been accepted i.e. There is a significant relationship between perceived risk and attitude toward online shopping and the remaining three hypothesis have been rejected i.e. there is no significant relationship between online shopping and perceived enjoyment, perceived ease of use and perceived usefulness. Out of four, Perceived Risk is the most significant factor that may affect online shopping behavior of consumers in Delhi. Perceived risk indicates the lack of trust among consumers and many other reasons like that of chance of being cheated, inferior quality of products, non returnable policy etc.

\section{Limitations Of The Study}

Although the objective of the study is met, but still there are some limitations of the present study.

- Firstly, the study conducted is limited to online consumers of Delhi.

- Secondly, the numbers of variables selected for the present study are few in number.

- Finally, the results are subject to common limitation of accuracy of response.

\section{Scope For Future Research Work}

The present study is based on limited number of variables which affects the consumer behavior to shop online. Therefore researchers can use different variables such as website design, reliability, internet traits, attitudinal traits etc to explore consumer behavior towards online shopping. Further, studies can be conducted by taking into account larger geographical area i.e. respondents from different states of India. Further researchers can also conduct research to examine consumers' intention to shop online with special reference to product categories and brands.

\section{References}

[1]. Davis, F.D, (1989) "Perceived usefulness, perceived ease of use, and user acceptance of information technology", MIS Quarterly, Vol. 13 No. 3, pp. 319-40.

[2]. Monsuwe, T.P.Y., Dellaert, B.G.C. and Ruyter, K.D (2004) "What derives consumers to shop online? A literature review", International journal of Service Industry Management, Vol. 15, No.1, pp. 102-21.

[3]. Stoel, L. Ha, S. (2009) Consumer e-shopping acceptance: antecedents in a TAM,” Journal of Business Research, Vol. 62 No. 5, pp. 565-71.

[4]. Zhou L., Dai, L. and Zhang, D. (2007) “Online shopping acceptance model - a critical survey of consumer factor 
[5]. Bhattacherjee, A, (2001) "Understanding information systems continuance: an expectation-confirmation model", MIS Quarterly, Vol. 25 No. 3, pp. 351-70.

[6]. Davis, F.D., Bagozzi, R.P. and Warshaw, P.R. User Acceptance of Computer Technology: A Comparison f Two Theoretical Models," management Science (35:8), August 1989, pp. 982-1003.

[7]. Childers TL, Carr CC, Peck J, Carson S (2001). Hedonic and Utilitarian motivations for online retail shopping behavior. J. Retailing 77:511-535.

[8]. Wolfinbarger M, Gilly MC (2001). Shopping Online for Freedom, Control, and Fun. California Manag. Rev. $43(2): 34-55$.

[9]. Bisdee, D. (2007). Consumer Attitudes Review. Office of Fair Trading, June, 1-147.

[10]. Beldona, S., Morrison, A.M., \& O'Leary, J. (2005).Online shopping motivations and pleasure travel products: a correspondence analysis. Tourism Management, 26, 561-570.

[11]. East, R, Consumer Behavior: Advances and Applications in Marketing. London: Prentice Hall, 1997.

[12]. Moon, J.W. and Kim, Y.G. (2001) "Extended the TAM for a world-wide-web context", Information and Management, Vol. 38 No. 4, pp. 217-30.

[13]. Culnan, M.J. Georgetown Internet Privacy Policy Survey, "Report to the Federal Trade Commission", http://www.msb.edu/faculty/culnanm/gippshome.html.

[14]. Koufaris, M., Kambil, A.. And LaBarbera, P.A., "Consumer Behavior in Web-Base commerce: An Empirical Study", International Journal of Electronic Commerce, Vol.6 No.2: 115-138, 2002.

[15]. Mathwick, C., "Understanding the Online Consumer: A Typology of Online Relational Norms and Behavior", Journal of Interactive Marketing, Vol.16, No. 1: 40-55, 2002.

[16]. Menon S, Kahn B (2002). Cross-category effects of induced arousal and pleasure on the internet shopping experience. J. Bus. Res.78:31-40.

[17]. Pavlou PA (2003). Consumer Acceptance of Electronic Commerce Integrating Trust and Risk with the Technology Acceptance Model"International J. Electronic Commerce, 7(3), 101-134.

[18]. Li,N. and Zhang P. (2002). "Consumer Online Shopping Attitudes and Behavior: An Assessment Of Research". Eighth Americas Conference on Information Systems. Kim, J. Fiore, A. and Lee, H. (2007).

[19]. Influences of online store perception, shopping enjoyment and shopping involvement on consumer patronage behavior towards an online retailer,Journal of Retailing and Consumer Services Vol. 14 PP. 95-107

[20]. Gefen, D., \&Pavlou, P. A. (2006). An inverted-U theory of trust: The moderating role of Perceived regulatory effectiveness of online marketplaces. Twenty Seventh International Conference on Information System.

[21]. Milwaukee Liebermann, Y., \& Stashevsky, S. (2002). Perceived Risks as Barriers to Internet and E-Commerce Usage. Qualitative Market Research: An International Journal, 5(4), 291-300.

[22]. Park, C., \& Jun, J. K. (2003). A cross-cultural comparison of internet buying behavior: Effects of internet usage, perceived risks, and innovativeness. International Marketing Review, 20(5), 265-335. 